\section{Plans for stem cell research could be blocked}

British researchers are awaiting the outcome of a Parliamentary free vote this month on whether they will be permitted to carry out embryo research using somatic cell nuclear transfer techniques. Although such research has considerable support within government, the specter of political opposition was raised at the end of October with the substantial defeat of a private members bill introduced into the House of Commons that would allow it to proceed.

Another blow came on 14 November, when the ethics advisory commission to the European Commission (EC) issued a report stating that permitting the creation of embryos by such techniques for the stem cell therapy was "premature." tive matter," such as the creation of embryos for research purposes, it is not sufficient to consider the end result of alleviating human suffering, but that the means employed need also to be considered. "In particular, the hopes of regenerative medicine are still very speculative and debated among scientists," says the report, adding, "there is a wide field of research to be carried out with alternative sources of human stem cells from spare embryos, fetal tissues and adult stem cells."

The British government has al ready signaled its support for embryonic stem cell research (Nature Med. 9, 950; 2000). Additional backing has come from a range of scientific bodies. The Royal Society, for example, issued a statement to Members of Parliament on 7 November describing the extension of current UK laws, which permit research on embryos up to 14 days old sirable." ment, in a meeting at Westminster. human cloning. vailed by a vote of 175 votes to 83 . eral election expected next year.

David Dickson, London
The EC believes that in a "highly sensi-

for certain purposes, to cover research aimed at stem cell therapies as "highly de

"MPs should accept that this research on early embryos is scientifically necessary if we are to ensure that patients benefit from the full range of potential treatments as quickly as possible," said Richard Gardner of the University of Oxford, the main author of the Royal Society state

A similar case was made the previous week by Euan Harris, Liberal Democrat MP for Oxford West, that would have allowed such research to take place in Britain. But Harris' proposal was strongly opposed by conservative MP Edward Leigh, a prominent anti-abortion politician, who objected to the research on three grounds: that it was unethical, that it was unnecessary, given the prospect of using adult stem cells, and that it could pave the way to

"[We] reject the claim by past totalitarian societies that medical research could put the interests of society over those of the individual," said Leigh. His position, which was backed by a number of MPs who said that they have received many times more letters expressing this 'pro-life' point of view than endorsing the research, pre

It remains to be seen in the face of such opposition both at home and in Europe, the government will be prepared to stick to its guns and offer a free vote as promisedor take fright and postpone any Parliamentary debate until after the gen-

\section{UK tries to increase physician scientist numbers}

In an effort to increase the country's quota of physician scientists, the Leicester Warwick Medical School has become the first institute in the UK to offer an accelerated four-year MD course-basic training to become a doctor normally takes five years-to students who al ready hold a first degree in the biological sciences.

The program is sited at the University of Warwick's Department of Biological Sciences which, during the last government Research Assessment Exercise was awarded the highest possible rating of $5 \mathrm{~A}$. The program welcomed its first intake of 64 students this year and enroll- ment is set to rise to around 200 in the next academic year as the institute bids to take on its share of the additional 1000 medical students that the country needs, according to a recent announcement by the Department of Health.

Funding has also been secured for an additional 17 non-clinical and four clinical lectureships. A new hospital nearby, incorporating a $f 15$ million (US $\$ 21.5$ million) clinical sciences facility will be built as part of the new program. There are also advanced plans to develop an MD/PhD course at the institute, an initiative that would be another UK first.

Simon Noble, London

\section{Gates Foundation hires preeminent scientist}

In line with hisphilosophy of recruiting the brightest and the best, Bill Gates has hired expert vaccinologist Margaret Lu as Senior Advisor in Vaccinology to the Gates Foundation and medical advisor

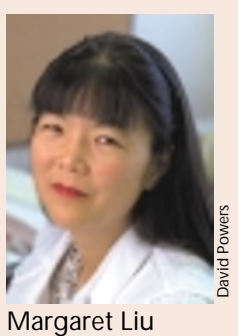
to the Global Fund for Vaccines.

The latter was launched in 1999 with a $\$ 750$ million inaugural grant from the Gates Foundation, and is dedicated to providing existing and near-term vaccines for the world's underserved children.

Liu will devote $75 \%$ of her time to this work and, because she is also an acknowledged authority on gene therapy, will be employed for the remainder of the time as vice chairman of the Board and chairman of the Scientific Advisory Board at Strasbourg-based gene therapy company, Transgene, a job that she began last month.

Transgene's technology platform is based on gene therapy vectors such as vaccinia virus, adenovirus and synthetic vectors. The company has five products in clinical development to treat a variety of cancer indications.

Liu-who is a member of the Scientific Advisory Group of the International Vaccine Institute in Seoul, Korea, and a member of the Board of Directors of the American Society of Gene Therapy-left her position as vice president of Vaccine Research and Gene Therapy with vaccine manufacturer, Chiron, in January when the company changed its strategic direction in vaccine research and decreased its gene therapy efforts. Prior to that, she was Senior Director of Virus and Cell Biology at Merck \& Co., and before that she was a faculty member at Harvard Medical School.

She says she took on the Gates role because she is "excited" about the impact that the Foundation is having on vaccine efforts: “They've really highlighted vaccines that need to be made for people that can least afford them. Not only those such as HIV, TB and malaria, but others that wouldn't command the attention or resources by any other route, such as guinea worm."

Karen Birmingham, London 